2002

\title{
The Emotions: Senses of the Modern Self
}

E. Doyle McCarthy

Follow this and additional works at: https://fordham.bepress.com/soc_facultypubs

Part of the Family, Life Course, and Society Commons, Other Sociology Commons, Sociology of Culture Commons, and the Theory, Knowledge and Science Commons

\section{Recommended Citation}

McCarthy, E. Doyle, "The Emotions: Senses of the Modern Self" (2002). Sociology Faculty Publications. 12. https://fordham.bepress.com/soc_facultypubs/12

This Article is brought to you for free and open access by the Sociology at DigitalResearch@Fordham. It has been accepted for inclusion in Sociology Faculty Publications by an authorized administrator of DigitalResearch@Fordham. For more information, please contact considine@fordham.edu. 


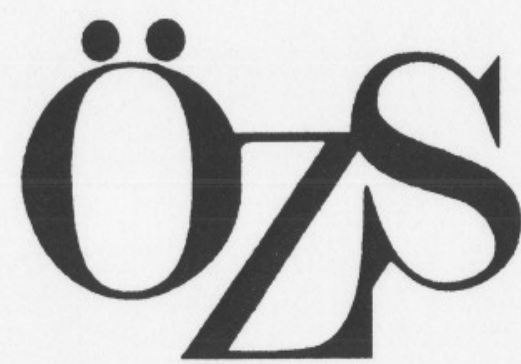

\title{
ÖSTERREICHISCHE ZEITSCHRIFT FÜR SOZIOLOGIE
}

\author{
Joachim Fischer
}

Simmels ,Exkurs über die Soziologie der Sinne'

Jens Loenhoff

Sinne, Kommunikation und Gesellschaft - Eine Theorieskizze

\section{E. Doyle McCarthy}

The Emotions: Senses of the Modern Self

Roswitha Muttenthaler

Gesellschaftliche Verfasstheit im Feld des Sehens -

Deutungsabsichten und verborgene AutorInnenschaft

Andreas Ziemann

Perzeption, Interaktion und die Ökologie der Gesellschaft -

eine systemtheoretische Suche nach den Sinnen 


\section{E. Doyle McCarthy}

\section{The Emotions: Senses of the Modern Self}

\author{
"... we say there are five senses. Yet we know there are more \\ (Diane Ackerman, A Natural History of the Senses) \\ "Society, then, provides extensive, incessantly renewed, often contra- \\ dictory lessons ... it feeds and thwarts, in a word, it educates, the \\ senses." (Peter Gay, Educution of the Senses)
}

\section{Preliminaries}

These extended considerations on the emotions of modern selves follow a line of inquiry that is sociological, specifically, how people's emotional experiences take their collective shape from the social (institutional) and cultural (symbolic and expressive) features of societies. This sociological approach develops and applies to the realm of human emotionality certain theoretical propositions from the sociology of knowledge whose starting point is collective - particular societies with their specific institutions, representations, and cultures. ${ }^{2} \mathrm{My}$ interest here is in the collective features of modern societies insofar as these bear on the study of the emotions: how modern notions of personhood - its standards of human feeling and being, as well as the ideas and social categories that modern persons use to define and to interpret their experiences - can be understood as particular constructs or features of a culture of modernity. Both of these phenomena - the social structure of modern societies and its culture of selfhood or identity - are used to describe the distinct experiences of emotion and affect of modern individuals. ${ }^{3}$

From the standpoint of the sociology of knowledge, the psychological features of individuals - experiences, emotions, and feelings - are socially constructed, meaning that the psychological sphere is permeated by social and cultural processes, including the entire cognitive and ideational realm of ideas, beliefs, social symbols, and language. Using this approach, the emotions can be studied collectively, that is, as ways of acting and being, as "cultural acquisi- tions" shaped by the social circumstances (social structure) and culture of a particular society, group, or community (Solomon 1984; cf. Gordon 1981, p. 563; Averill 1980; Harré 1986, 1991; Lupton 1998, pp. 15-17). Among the many outcomes of this approach is a view of human emotions as possessing "socially emergent properties" - properties that "transcend psychological or physiological explanation" (Gordon 1981, p. 562; 1989). These emergent properties are explicable only in relation to other social phenomena: emotions combine features of body, gesture, and cultural meaning. Today this approach to emotion studies is representative of a number of different "social constructionist" works (Harré 1991; Lupton 1998; Williams 2001, pp. 45-50).

Constructionism's most prominent feature is an emphasis (one that varies considerably from study to study) on the cognitive and cultural features of emotion. This emphasis it shares with many cognitive psychologists working in emotions and with those identified with the social constructionist movement in psychology (Gergen 1985; Gergen and Davis 1985; Averill 1980, 1982, 1986; Harré 1986), as well as with a number of works in cultural anthropology (e. g., Lutz 1988; Shweder and LeVine 1984) and philosophy (de Sousa 1987; Rorty 1980; Solomon 1984). Studied this way, emotions are construed as acts or as symbolic actions or "cultural performances" (Averill 1986, p. 100), involving both cognitive and physical processes. These formulations are intentionally employed to provide alternatives to those views of emotions as principally bodily, experiential or irrational phenomena. Among the many important features of this approach to emotions is a historical view of human emotionality with its emphasis on changes in the social and cultural environments in which the emotions are experienced and known as well as an interest in the range and variations of human experience (Reddy 2001; Lewis and Stearns 1998): the historical forms of personhood, the relations of human beings with the body, the relationship of various discourses (religious, medical, scientific, legal) and cultural practices to bodily functions, the forms of physical pain and pleasure and their changing social meanings. One principal outcome of these studies has been an emerging history of emotions or, more accurately stated, the discovery that "emotions have a kind of history" (Reddy 2001, p. x), as scholars from medievalists to modernists have come upon various revolutions in the domain of feelings and judgments about feelings, their cultivation, control, or expression.

Arguments for a history of emotions follow logically upon a sociocultural approach to the emotions. For if the emotions are preeminently cultural phenomena, the principal contexts for their study are the cultural systems and social worlds where they are experienced and known, the particular political and reli. gious systems, the various discourses, the collective practices, and the forms of selfhood that prevail among particular groups and societies. Put differently, it is 
in and through (historically particular) cultural systems that emotions have come into being as something, that is, as objects of experiences that mean something, and as a differentiated system of signs with which the self engages. A history of emotions is particularly suited to address the question of how precisely and in what ways, cultures of sentiment and emotion - standards, ideas, precepts concerning how to feel and what to feel and what feelings mean - and emotional experiences themselves, actually change.

At the forefront of emotion studies is the idea that emotions change, since the emotions - and this is also a way of understanding the self - are the products of collective acts of interpretation. To know how and what to feel, to be conscious of emotional experiences is, to cite Walker Percy (1958), to be "conscious of something being something." Emotions and feelings come into being as something, that is, as objects of our experiences that mean something and as a differentiated system of signs with which persons engage. This returns us to the system of culture in which any object - an emotion, a person, an event - is know and interpreted as something. The emotions, for example, have a range of historical meanings closely associated with aspirations concerning self-control, with religious salvation or redemption, with self-integration or wholeness, with one's moral goodness or sinfulness, and with the meanings a person gives to her ability to control what she feels and how she feels it. Today, as many have observed, the emotions have become signifiers of how much and how deeply we feel things (or fail to feel things). According to many commentators on the emotions today, the social world of late modernity is distinguished by both an enormous popular and scientific concern given to the emotions. As some have argued, emotional experiences have become the foundation of what it means to fully be a "self," to apprehend who I am and want to be. Feelings and emotions have come to serve as one of the principal experiences of self-validation, as the moorings, the moral and spiritual resources, from which to claim an identity and to build a self-conception. "To find out what one feels becomes a search for oneself" (Sennett 1974, p. 336; cf. Bellah et al. 1986, chap. 6; McCarthy 1989a; Barbalet 1998; Giddens 1991; Lowney 1999).

What follows is an argument for emotion studies that is both cultural - focussed on cultural systems of meaning as the locus of human emotionality - and historical, arguing that sociocultural changes across time will, in turn, be registered in the domain of human sentiments and experiences, although how precisely culture and experience change relative to each other is a matter to be investigated. The question at hand is on the emotions of modern persons - a distinct culture of selfhood and an accompanying emotionality, a special relationship to the body and its functions, an identifiable set of standards of emotional control and expression - in fact, many of these topics have already been identi- fied with a history of modernity in its different phases: in the early modern period with its rules and new standards of "civility" and etiquette and an accompanying rise in self-consciousness about the artful process of self-presentation (Elias 2000; Greenblatt 1980); with the $18^{\text {th }}$ century rise of "sentimentalism" (Reddy 2001; Taylor 1989), an emotional regime that, in its full flowering, ex. tolled emotions as both natural and morally good; with the development of nineteenth century "sentimentality," expressed in a Victorian reserve in matters of feelings - a reserve that struggled with the widely accepted view of the "vitality of feelings" (Gay 1984, p. 455).

Using the framework I have outlined here, I will locate the emotions as "senses" of the modern self, arguing that the emotions have taken on specific meanings within modernity's history, that the emotions have become special objects of attention and elaboration for modern selves or "subjects." What I mean by the emotions as senses of modern selves - I mean this figuratively, as I mean to capture what emotions are in the everyday sense of things - is that the emotions have taken on some of the historical meanings of the five senses - vision, hearing, touch, smell, taste - as vehicles of knowledge of the world, as so many channels transmitting to our minds and consciousness the (external) realm of reality. Today, the emotions, what and how and how much we feel, have become paramount features of our encounter with the world, an encounter that, in contrast to the encounter of our senses with the world, is an inward encounter. Just as the senses were said to link the knowing subject with the objective world (the "known"), the emotions represent a new direction, a new movement, and a new location of knowledge for modern subjects - an inwardness, a new interior domain where the emotions are housed. The emotions, we are told today, emanate from deep within the self, as signifiers of our inner depths and spaces, "their sublime origin" (Reddy 2001, p. 316). A history of modern emotions can begin here, with a cultural history, however tentative and incomplete, with the formation of modern inwardness, the sense that we are beings with inner depths wherein our truest self resides.

\section{The Contours of Modern Selfhood}

At whatever moment we enter the history of modern selfhood - with Freud's monumental creation of its interior topography, or with nineteenth century accounts of modern bourgeois individualism, or with its beginnings in Renaissance humanism, what Burckhardt (1954) called the development of the free or "spiritual individual" - we discover in this process something new and distinctive in the human person, its inwardness. By inwardness, I do not mean 
what philosophers call self-consciousness, that universal ability to distinguish ourselves and our own experiences from others and from our worlds; nor do I mean the reflexive quality of human thought and speech where, in thinking and in speaking, one's thought and speech becomes part of a deliberate and conscious repertoire inserted into our human relations and intercourse. To claim that only modern persons can be so characterized is to deny to all but a few what is clearly a mark of us all: we are signifying beings, both reflective and dialogical.

The meaning of inwardness I wish to convey is a disposition - moral, spiritual, and psychological - one that in modern societies has come to be viewed as a social good. To be a self, according to modern cultural meanings, involves persons in the pursuit and acquisition of self-knowledge, a knowledge not for its own sake but for the purpose of controlling and for "fashioning" one's selfhood or identity, for making up oneself, for articulating one's own presence in the world. "Self-fashioning," as Greenblatt (1980, p. 1) calls it, is not an invention of modernity; there were selves and "a sense that they could be fashioned" before this era. But what was born in the early modern era of the sixteenth century was both an "increased self-consciousness about the fashioning of human identity as a manipulable, artful process" and a new-found sense of autonomy: "the power to impose a shape upon oneself is an aspect of the more general power to control identity - that of others at least as often as one's own" (Greenblatt 1980, p. 1; cf. Elias 2000, pp. 85-109).

This inwardness is also a disposition that has attached us, relative to other peoples and civilizations, to ourselves, an argument made first by Tocqueville (1990). Durkheim (1984, p. 122) elaborated it later, and more systematically, in his study of the industrial division of labor:

There is indeed one area in which the common [collective] consciousness has grown stronger ... in its view of the individual. As all the other beliefs and practices assume less and less religious a character, the individual becomes the object of a sort of religion. We carry on the worship of the dignity of the human person which, like all strong acts of worship, has already acquired its superstitions ... It is indeed from society that it draws all its strength, but it is not to society that it binds us: it is to ourselves.

This disposition has also given to the domain of the "subjective" and "personal" decidedly emotional social values - values of sentiment. This is because the modern self is directed to a field of new objects - objects that exist in a new social space, a world of inner objects (Charles Taylor's term), objects whose meaning and significance hardly existed before - before when? The seventeenth century, that age of sentimentalism when modern "subjectivity" and its "culture of interiority" might be traced (DeJean 1997, chap. three). Or, with the eighteenth-century theory of the sentiments, a later change when sentiments became "normative" (Taylor 1989, p. 284):

Sentiment is now important ... because undistorted, normal feeling is my way of access into the design of things, which is the real constitutive good, determining good and bad.... The new place of sentiment completes the revolution which has yielded a modern view of nature as normative, so utterly different from the ancient view ... endorses nature as the source of right impulse or sentiment... Nature as norm is an inner tendency; it is ready to become the voice within, which Rousseau will make it, and to be transposed by the Romantics into a richer and deeper inwardness.

Taylor elaborates this "massive shift" in the making of the modern identity and in its valuation of emotions in two ways: first, by the eighteenth century there is an entirely new understanding of the "subject" where thought and valuations are psychic phenomena - they are in the mind; "what was previously seen as ex. isting ... between knower/agent and world, linking them and making them inseparable" (Taylor 1989, p. 188), is now seen as belonging to the subject. Taylor and others have called this shift "a new subjectivism."4 "Thought and feeling the psychological - are now confined to minds" (Taylor 1989, p. 186).

Secondly, Taylor elaborated this "massive shift" in its corresponding notion of the good - its love of nature and its "cult of sensibility" - and traces its development in philosophical texts, but also other works that trace in the history of commercial activity, in marriage and family life, in religious movements and revivals (among Pietists and Methodists), and in the rise of the modern novel, changes in sentiments, ethical outlooks, and new understandings about nature's vitality and the importance of "inner life" and feelings as "moral sources" of the modern person. In this way, Taylor documents movements that both reflected and helped to usher in the rise of a modern and individualist culture: it values personal autonomy; it renders "self-exploration" important, particularly the understanding of one's emotions; its "visions of the good life ... involve personal commitment" (Taylor 1989, pp. 285-86). I am highlighting Taylor's careful tracing of the history of the modern self - a self of sentiments and a sentimental self - as a way to describe its important discursive sources; this is an intellectual (principally, philosophical) historical study and not a work of "historical explanation." ${ }^{5}$ Despite this, it is also a project whose arguments about moral discourse and human understanding assume a distinctive theory of the self, one that can be used to examine how the emotions today carry such cultural weight and are both socially and politically consequential.

Taylor's idea of the self - one that is clearly different from dominant theories of the self in social science today - is that the self is a being constituted in the 
taking of moral positions, of acting relative to "goods," however differently understood in particular historical and cultural circumstances. His question: how did modern notions of the good develop along with new understandings of human agency and selfhood? I will return to this question again, for it contains a proposition about the emotions as powerful cultural objects (McCarthy 1989a; 1989b) whose momentum derives from their interior location as natural forces within, as inner essences. As many have argued, these inner essences (emotions) have been with us since the cultural transformations of the seventeenth century and the movements of eighteenth-century Enlightenment and Romanticism. However, the emotions have clearly taken on different social meanings over time. Put differently, there is a "vocabulary of the emotions" whose history continues to be traced today - a "shared body of words and meanings . . . significant, binding words in certain activities and their interpretation" (DeJean 1997, p. xiii, 91; cf. Williams 1983, p. 15). Today's "vocabulary of emotion" (just as with today's particular forms of "inwardness") still needs to be written. And while we know something of its sources in early modern history - a history of emotions traced, however differently, by Taylor's (1989) intellectual history of modern inwardness and Reddy's (2001) proposal for a history of emotions, today's "emotions" belong to a vocabulary of more recent origin whose "key words" (Raymond Williams's phrase) might include: self, identity, freedom, authenticity, psychology, pleasure, culture, nature. It is to that, more recent, history and culture that I now turn.

\section{Civilizing Processes and Modern Emotionality}

Sociologists of emotion claim a variety of classic works as part of its current perspective and set of research problems. ${ }^{7}$ Among these works, Norbert Elias's The Civilizing Process, is singled out for its examination of human emotionality within a framework of social and historical change. The direct relevance of this work to a discussion of modern "inwardness" and its valuation of emotion and feeling is to be found in its argument that the social changes associated with modernity (most especially, greater social differentiation and the increased interdependencies that coincided with the formation of states and the centralization of power) were accompanied by simultaneous changes in the body and its functions: an increased capacity for self-consciousness and self-monitoring; increased levels of shame, embarrassment, and disgust associated with the body and its functions. These changes also coincided with the rise in a distinct consciousness of self - an increased sense of "autonomy" and an accompanying separation of the self from the "outside world" (Elias 2000, pp. 472 ff.).

36 Özs 27. Jg.
There is a close relationship of each of these changes to Taylor's account of "inwardness" and modern identity, ${ }^{8}$ although Elias provides rich and extensive materials from social and institutional history to advance his social and historical argument about the modern self and its development. In what follows, I will highlight some of Elias's principal accounts of the historical development of the "civilized" person in modern European societies and its accompanying notion of the self-controlled, privatized individual, autonomous and self-conscious arguments that bear most closely to an emotional portrait of modern selfhood.

Elias provides a distinct emotional history by giving us a history of etiquette. His thesis is that the history of Western society from the late Middle Ages to the nineteenth century represents a gradual transformation in people's ideas (and later, their behaviors) concerning manners and bodily propriety, changes associated with a number of factors, particularly (in its early phases), the importance of court societies with their codes of behavioral and emotional deportment. Central to this transformation were decisive changes in the feelings of shame, repugnance, and embarrassment that attended a wide range of bodily functions such as eating, spitting, nose-blowing, urinating, and defecating.

This history of manners can be read as a history of a word and a concept, "civilization": first, the courtoisie or courtliness of the Middle Ages, next the civilité of the Renaissance through the early sixteenth century, and finally, civilisation of the late eighteenth and nineteenth centuries. The words signify moments in the long-term process of social and psychological development. Each indicates different standards of conduct within a sequence of change. In its fullest development civilization refers to Western nations' consciousness of themselves as bearers of a stage of human and social development, a consciousness of their own superiority in morality, law, and in their scientific and artistic achievements. The development of this idea coincided with a long-term trend: affect and impulse came under increasingly tighter social and personal controls and shame thresholds advanced accordingly.

Elias sees a transition to a new and different standard of behavior introduced in De civilitate morum puerilium ("On civility in children") by Erasmus of Rotterdam, published in 1530 - a standard represented by civilité which acquired its meaning during the second quarter of the sixteenth century when chivalry and the unity of the Catholic church were disintegrating. This highly influential treatise by Erasmus (it had over one hundred and thirty editions and appeared in many translations) reveals a new sensitivity about how people should conduct themselves in society, extending beyond table manners to bodily propriety - carriage, dress, and facial appearance and gestures. While many of the earlier directives from courtesy books are repeated by Erasmus, one detects a new way of seeing, of distancing oneself from what one sees. There is a greater sensitivity 
to how one appears to others. Erasmus's own precepts reveal a careful eye and he exhorts his readers to be observant. Civility, as Elias notes, is removed from mere courtesy and closely bound up with a manner of seeing. Look about you, Erasmus urges, and pay attention to people, their feelings, and their motives. For Elias, this signifies a critical moment in the history of the civilizing process: human behavior takes on a different character seen in the increased tendency to ob. serve oneself and others. According to this standard, "people moulded themselves and others more deliberately than in the Middle Ages" (Elias 2000, p. 68). As the demand for self-control was raised, controls became more internal and unconscious (2000, p. 109; pp. 117-19; pp. 365-87). In this way, Elias speaks of certain affect-expressions becoming, in time, "privatized," or "forced into the 'inside' of individuals, into 'secrecy' ..." (Elias 2000, p. 121).

Elias's historical argument - I highlight only those aspects that pertain to modern identity and emotionality - is fruitfully read alongside Taylor's treatise on the discursive history of modern identity (in philosophy, theology, literature, etc.). Regardless of the important methodological differences that separate them, both provide a portrait of modern selfhood as a structure that has, in time, moved inward. This interior movement - we think of feelings and thoughts as "inside" or "within" - has many sources and expressions: increased social controls on instincts and emotions become internalized; the body and its functions undergo a "civilizing" process that renders this domain private and intimate; the "civilizing" process coincides, in important ways, with an "increasing split between an intimate and public sphere, between private and public behavior" (Elias 2000, p. 160). This divided self is also a self whose interiority is nature within us (Taylor); our "inside" or our interiority is the place where we discover - in sentiment and feeling - not only who we are, but Nature itself brimming within us: "The world about us would be desolate except for the world within us."

Elias's argument - that increased (social) controls corresponded to an increase in (personal) controls and an accompanying rise in levels of shame and anxiety - is a sociohistorical argument, despite its resonance with Freudian theory (Elias 2000, p. 442):

we realize the degree to which the fears and anxieties that move people are human-made the strength, kind and structure of the fears and anxieties that smoulder or flare in the individual never depend solely on his or her own "nature"... They are always determined, finally, by the history and the actual structure of his or her relations to other people, by the structure of society; and they change with it.

Modern history tells us how much culture matters in this process. How the modern disposition or habitus is a construct of changes in European standards of be- havior, standards thrust into social life as sociopolitical interdependencies changed - changes that coincided with modern civilization's development: "The fortunes of a nation over the centuries become sedimented into the habitus of its individual members" (Elias 1996, p. 19).

\section{Emotion Studies: A Discourse on (Post)Modern Selfhood}

But what about the emotions and the self today, in this phase of modernity's history? Recent studies by sociologists of the emotion address the general question of how and why the emotions are important in today's world (Barbalet 1998; Lupton 1998; Williams 2001) and each of these address the "civilizing" thesis of Elias and its contemporary relevance, a topic I will return to shortly. In addition, there is a growth of sociological studies that address the role of emotions in multiple forms and contexts of social life: for example, in consumer cultures and mass media; the rise and growing influence and popularization of "therapeutic culture"; emotions and the problem of social controls - rising crime and violence - in advanced capitalist societies; the changing standards of behavior and feeling ushered in by globalization; the role of emotions in "identity movements" of races, ethnicities, nations, and sexualities. Studies of contemporary culture, such as these, share a recognition of the importance of thinking about emotions in a world where emotions have become more and more manifest.

However much the emotions have been neglected in previous eras, in contemporary social science they have become one of its central concerns: in popular culture such as studies of television "talk shows" (Lowney 1999); in studies of intense emotions involved in social movements (Goodwin et al. 2001); in mass media where "entertainment" and "celebrity" rule and transform news and politics (Gabler 1998); in sports and leisure where emotions are aroused (Dunning 1999); and in studies of emotions in everyday life (Katz 1999; Swidler 2001). Emotions are seen as ingredient to our leisure, fun, and massproduced utopias (Illouz 1997). "Capitalist culture" has become, in the last half century, a powerful carrier of a culture of hedonism, pleasure, and release (Bell 1996). These are some of the themes of contemporary emotion studies.

In several important respects, these studies have begun to capture - in a descriptive way - today's particular "structure of feeling" (Williams 1973) and how it has become a culture distinguished by so many emotional pursuits (in leisure, sports, relations with other, consumption) and emotion talk. It can even be said that we live today in a world of emotions, a world where psychology has become a mass idiom and where feelings are the topic of endless talk - on radio and television "talk shows"; in the offices of practitioners whom we seek for ad- 
vice about our "emotional lives"; in the exchanges we have with friends and intimates about what we feel, how deeply we feel, and what these feelings mean. In public life, we witness collective displays of emotions - the rise of spectator sports and their mass consumption, rock and rap concerts, the new political conventions in the U.S., mass meetings of churches and religious assemblies as well as new public monuments and memorials ("shrines to sentiment") and new museums to mark and to remember assassinations, atrocities, and human disasters. Despite the vastly different emotional forms and sites of these examples, they share in common certain features of modern identity: we are - in important ways - constituted by our emotions and feelings. Self-expression, particularly the expression of our emotions, is an expression of our truest and most inner natures as persons. Emotions and feelings - "getting emotions out" and "emotional pursuits" are vital aspects of today's cultural practices as well as each person's "emotional habitus" (Kane 1997; 2001). The narrative history of modern identity and emotionality - our emotions are powerful inner forces of nature and our deepest selves - is a narrative played out on today's cultural landscape.

If the discourse of self, as Calhoun (1994b) has written, is a modern discourse about the social location of modern individuals, then the discourse of emotion is also a discourse about modern selfhood and identity. Many of the studies to which I just referred return to the problem of identity: particularly the unfolding and seemingly unchartered and ungrounded domain of people's identities, about which so much has been written in the last decade (Appiah and Gates 1995; Aronowitz 1992; Balibar and Wallerstein, 1991; Calhoun 1994a; Gergen 1991; Giddens 1991; Lash and Friedman 1992; Parker et al., 1992). For feelings and emotions serve as one of the principal experiences of self-validation, as the moorings, the moral and spiritual resources from which to claim an identity and to build a self-conception. Within late modernity - for reasons discussed here the emotions have become precious vehicles for rendering one's life and one's identity meaningful.

Anthony Giddens's writings $(1991 ; 2000)$ on contemporary social movements highlight those particular features of late modernity that are linked to a new and distinct type of political movement called "identity politics" such as movements based on ethnicity, race, or gender and with issues of the body such as abortion politics, and movements linked to current ideologies of selfhood, what Giddens calls "life politics" (1991, p. 214) and the ethos of self-growth. Life politics, Giddens writes, "concerns political issues which flow from processes of self-actualization in post-traditional contexts, where globalizing influences intrude deeply into the reflexive project of the self, and conversely where processes of self-realization influence global strategies." Demonstrations of re- cent decades in the U. S. involving abortion rights and pro-life politics and world-wide political movements of groups (classes, nations, ethnicities, races) seeking to affirm and to achieve political and personal recognition are some of the sociocultural sites where political passions are mobilized, passions whose intensity require multifaceted inquiries to account for them, inquiries that examine how human identifications are structured and restructured socially and politically, moving between intense primary bonds of family and the "grand identifications" of nation and race (de Swaan 1992; cf. Anderson 1991; Calhoun 1991a).

Giddens (1991, pp. 217-18) contends that in the present social and political context it is difficult to distinguish "life-political" identity issues and concerns focussed on the body. For today, neither the body nor one's identity are commonly viewed as natural objects. Today, both are increasingly subject to discursive practices and reflexive action (self-help texts and techniques, therapies, exercise machinery and manuals, sex changes, plastic surgery for breasts and noses, organ transplants). The embodied self has become a "site of interaction," worked on by the techniques and the practitioners of high modernity. "The body itself," Giddens writes, "as mobilized in praxis - becomes more immediately relevant to the identity the individual promotes" (1991, p. 218) or an identity promoted by society. The body is that last domain of privacy and secrecy, that site of emancipatory acts and politics.

The work of Giddens (1991) extends the argument of Elias (2000) on the self-reflexive and self-monitoring features of modern identities. Studies by Wouters $(1992 ; 1998)$ directly address the issue of emotional self-controls and emotional self-monitoring as continuing dimensions of identity and emotion today. He argues that the civilizing process and its accompanying controls have become both more varied and increasingly "subjective" or individualized, that is, relegated to a person's capacities for reflexive self-monitoring and control, due, in part, to the growing differentiation of societies in late modernity. These trends have coincided within the increasing "emancipation of emotions" as part of a long-term process of "informalization" - due to the relaxation and differentiation of behavioral, emotional, and moral standards (Wouters 1992, p. 229; cf. 1999). An important feature of emancipation and informalization has been the dissemination of "emotion knowledge" (McCarthy 1989a) or a heightened consciousness about emotions through education, mass media, and the role of therapeutic culture in contemporary life. Informalization is also associated with the growing conviction of many that emotional controls should be relaxed. Wouters points to a "new level of reflexive civilization" (1999, p. 424) - internal and self-conscious processes of monitoring one's own internal states and social behaviors as well as those of others - as ingredient to the growth of 
emotional "permissiveness" and "informalization." This argument parallels Giddens's argument, discussed above, on the increasing reflexivity of contemporary identities: "the reflexivity of modernity extends into the core of the self ... the self becomes a reflexive project" (1991, p. 32).

\section{Conclusion: Alienation in an Age of Emotion}

Recent studies have pointed to an alienation of emotion that coincides with today's consciousness of emotion and feeling. There are many discussions of the sources of this experience, some of which have entered the social science literature. Barbalet (1998, pp. 171-176) describes a "narrowing of emotional experience," arguing that it is associated with subjectivization or the reduction of social reality to the domain of the self or the reduction of the human capacity for feelings and emotions to self-feelings and emotions, such as self-esteem, self-hatred, embarrassment, shame, or anxiety. In Barbalet's words (p. 172):

the rise of emotion as a focus of widespread and popular concern at the present time operates through a double process: a shrinking of the phenomenal world to the self, and self-experience as the defining force of what constitutes emotions.

Not only is reality reduced to its apprehension by individuals, but the complex - sometimes momentous - events in the world today are construed in highly personal terms and in the popular idiom of psychology. Among the many effects of this "shrinking of reality" is the trivialization of human events and human feelings: the measure of things is not only ourselves, but our feelings about things and ourselves.

Other commentators describe the sources of this alienation as an effect of rationalization (in Max Weber's meaning of the world) or the "disenchantment of the world" where life-experience is reduced to instrumental reason or framed within the utilitarian values of our commercial civilization: the traditional matrices which gave meaning to life have been replaced by purely instrumental patterns of action: life has lost its purpose, its depth of meaning; there is a loss of passion - themes of modern writers from Tocqueville to Kierkegaard and Nietzsche.

This is a difficult and elusive topic to address, particularly from the standpoint of sociology. However, we might do so through the concept of the emotions as a master symbol - and in a way that extends our commentary on modern inwardness and emotion as both historical and social constructs. As a master symbol, the emotions sum up many emotional themes of contemporary life in this world of runaway change:
Emotions are real and natural signs of our true selves, keys for unlocking our personal and inner lives; the emotions operate as the touchstone of the modern self in a fabricated world.

Emotions are signs of our abilities to control our lives and our destinies; and just as modern selfhood has been conceived as a project of self-fashioning, the emotions are artful productions of reflective selves.

Real emotions elude us. In our overly-managed world, a world where emotions are "packaged" and consumed along with other products of the market, what we really seek is to really feel. Despite all our emotion talk and our emotional labors, we suspect that all along we have not felt - or felt deeply - at all.

Does our incessant emotion talk and emotional pursuits belie the recognition of our alienation - not only from "emotion" but from passion as well? Is our intensified emotion consciousness also seen as an expression of our sense of displacement in the realm of our feelings - that quality of lost spontaneity both in our ability to feel and in our ability to identify with what we feel about our feel. ings (McCarthy 1989a, p. 65)? We not only "have strong feelings about [our] feelings" (Stearns and Stearns 1986, p. 15), we also have fears and anxieties about our feelings and about our inability to feel (Sennett 1974, p. 324).

However, these fears may not have been born from our very own overly managed, manufactured, and monitored world. Writing at the approach of our recent fin de siècle, Joan DeJean (1997, p. 123) described that momentous and first fin de siècle, at the turn of the eighteenth century, as an age very much like our own in matters of the heart:

desirous of interiority and engaged in the collective creation of an obsession with affective precision because it was terrified of emotional emptiness ... individuals not fully in touch with their hearts and so frozen by affective paralysis that they only realize what they are/were feeling after the fact.

Cultural inquiries such as DeJean's, as well as the many recorded here, push emotion studies into an area of study as yet unexplored: studies of our emotion sciences as themselves cultural formations, inquiries into the ways that academic knowledges (including our sciences) are cultural texts that "say" something about the specific contours of selfhood and affectivity for us today, studies that address Michel Foucault's question: "What are we today?" "What are we in our actuality?" (1988, p. 145). His line of inquiry concerned the exact history of our present self-attentiveness - the technologies that permit us to affect our bodies, souls, thoughts, relations, and action and, in such as way, that we achieve authenticity, happiness, peace, and purity $(1988$, p. 18).

According to the cultural logic I have used here - the emotions can be studied as collective représentations of contemporary world (McCarthy 1989a, pp. 66-67), 
as preeminent molds for our mental lives, one of the ways the contemporary mind represents to itself its encounter with the world, in much the same way that Lévi-Strauss (1969) portrayed "totemism," not as a thing in itself, not even as a system or set of practices of primitive peoples involving animals or plants. The theory of totemism signifies something about ourselves, he argued. "Totemism is like hysteria," the book opens. They both arise "from the same cultural conditions;" they entail a strategy, one "common to many branches of learning toward the close of the nineteenth century, to mark off certain human phenomena ... which scholars preferred to regard as alien to their own moral universe ..."

Emotions, I suggest, can be conceptualized and studied in much the same way as Lévi-Strauss portrayed totemism: as "cultural artifacts," as sign-systems operating in the realm of mass culture (Barthes 1972, p. 9), as powerful and mystifying things, a feature of this mystification, their capacity to reveal to us the greatest truths about our selves today (Turner 1976; Benton 1993).

If we think about emotions studies (or our sociologies, psychologies, philosophies) as cultural texts, as Lévi-Strauss did of totemism, we might begin to provide readings of these texts and their discordant, conflicting, and incommensurable messages ("findings" and "theories") about what the emotions are and what a self is. In contrast to sociology's long standing attempt to "nail down" empirical facts about emotions, a cultural reading might find in these incommensurable findings about the emotions, a peculiar kind of cultural sense. For "culture" is not neutral, nor does it speak in a single voice. Our science of emotions might be "read" as a kind of register of these unresolved questions about what $a$ self is and what our feelings mean, questions articulating our present pre. occupation with what we are: how our actions are our own and not our own... whether or how we are selves or constructed selves, and in what ways. Are we our own creation or in thrall to forces outside us? Are we natural beings or are we unbearably unnatural? Are we feeling deeply, or not at all? What do our feelings and emotions tell us, say to us? Emotions - senses of (our) selves, eyes and ears of our (modern) souls.

\section{Notes}

1 For earlier statements on this paper's themes see McCarthy (1989a; 1994).

2 The idea that modern individuals have distinct characteristics as selves is an idea studied and elaborated in different fields of study including social psychology, sociology, history, and philosophy. Several recent projects in the social sciences that address this topic are McCarthy (1994), Williams (2001), Lupton (1998), Lutz (1988), Wouters (1992), and in history Stearns (1994), Stearns and Lewis (1998), and Reddy (2001). Taylor's (1989) comprehensive philosophical study of the modern subject and its interiority also address- es the rise of modern "inwardness" and sentiment. In psychology, Gergen's work (1991; 1999; 2001) has been, in important ways, related to these themes in the humanities.

3 The field of the sociology of knowledge has typically examined the entire ideational realm (knowledges, ideas, mentalities, etc.) and their social locations. More recently it has been applied to the study of human psychology and to such topics as the social self or identity. Early statements include Berger (1970; 1977), Farberman (1973), and McCarthy (1989a).

4 Taylor used this phrase $(1989$, p. 188) as others have also used it to describe the modern identity. For example Berger has used it in his discussion of the "pluralization of lifeworlds" (1967; cf. Berger et al., 1973); Gehlen's Man in the Age of Technology (1980) uscs "subjectivization" explicitly and bears a close relationship to some of the themes of this paper.

5 For a full discussion of Taylor's methodology see Craig Calhoun's (1991b) article. Calhoun criticizes Taylor for his neglect of the sociological factors that bear directly on his subject. Despite this criticism, Calhoun argues that Taylor's work is an excellent starting point for understanding the self as moral subject.

6 For a documentation and critical use of recent writings in a modern history of emotions, see William Reddy's (2001) study whose principal research setting is Revolutionary France and its sentimentalism in literature and philosophy. See also his (1997) The Invisible Code: Honor and Sentiment in Postrevolutionary France, 1815-1848.

7 Included here might be Max Scheler's The Nature of Sympathy (1954) and his Ressentimen (1961), Georg Simmel's (1950) treatment of the social psychological implications of secrecy and betrayal, and Helen Merrell Lynd's work (1958) on the role of shame and its relationship to guilt. Harold Bershady (1992) has provided for the English reader a valuable edited collection of Scheler's writings as well as an introduction to his work.

8 Sec, in particular, Elias's 1968 "Postscript" in The Civilizing Process.

9 Taylor (1989, p. 493) cites a poem (of which I cite only one line) of Wallace Stevens from his Opus Posthumous, quoted by Stephen Spender The Struggle of the Modem (London: Hamish Hamilton) 1963, p. 39.

\section{References}

Ackerman, Diane. 1990. A Natural History of the Senses. New York: Random House.

Anderson, Benedict. 1983/1991. Imagined Communities. Revised and extended edition. New York: Verso.

Appiah, Kwame Anthony and Henry Louis Gates, Jr. 1995. Identities. Chicago: University of Chicago Press.

Aronowitz, Stanley. 1992. The Politics of Identity: Class, Culture, Social Movements. New York: Routledge.

Averill, James R. 1980. "A Constructionist View of Emotion." Pp. 305-39 in Theories of Emotion, edited by R. Plutchik and H. Kellerman. New York: Academic.

- 1982. Anger and Aggression. New York: Springer-Verlag.

- 1986. "The Acquisition of Emotions During Adulthood." Pp. 98-119 in The Social Construction of Emotion. Ed. R. Harré. New York: Basil Blackwell.

Balibar, Etienne and Immanuel Wallerstein. 1991. Race, Nation, Class: Ambiguous Identities. New York: Verso. 
Barbalet, J. M. 1998. Emotion, Social Theory, and Social Structure: A Macrosociological Ap proach. New York: Cambridge.

Barthes, Roland. [1957] 1972. Mythologies. Translated by A. Lavers. New York: Hill an Wang.

Bell, Daniel. 1996. The Cultural Contradictions of Capitalism. With a new afterword by the author. New York: Basic.

Bellah, Robert N., Richard Madsen, William M. Sullivan, Ann Swidler, and Steven M. Tipton. 1986. Habits of the Heart: Individualism and Commitment in American Life. Berkeley, CA: University of California Press.

Benton, J. S. 1993. "Self and Society in Popular Criticism: 1920-1980," Symbolic Interaction $16(2): 145-70$

Berger, Peter L. 1967. The Sacred Canopy. New York: Doubleday.

- 1970. "Identity as a Problem in the Sociology of Knowledge." Pp. 373-384 in The Sociolo gy of Knowledge. J. Curtis and J. Petras, eds. New York: Praeger.

- 1977. "Toward a Sociological Understanding of Psychoanalysis." Pp. 23-34 in Facing Up to Modernity. Ed. P. L. Berger. New York: Basic Books.

Berger, Peter L., Brigitte Berger, and Hansfried Kellner. 1973. The Homeless Mind. New York: Random House.

Bershady, Harold J. 1992. "Introduction." Pp. 1-46 in On Feeling, Knowing, and Valuing. By Max Scheler. Edited and with an Introduction by Harold J. Bershady. Chicago: Uni$v$ ersity of Chicago Press.

Bolton, Richard. 1992. Culture Wars: Documents From the Recent Controversies in the Arts. New York: New Press

Burckhardt, Jacob. [1890] 1954. The Civilization of the Renaissance in Italy. New York: The Modern Library.

Calhoun, Craig. 1991a. "Indirect Relationships and Imagined Communities: Large-Scale Integration and the Transformation of Everyday Life." Pp. 95-121 in Social Theory for a Changing Society. edited by P. Bourdieu and J. Coleman. Bolder, Colorado: Wery for a Press.

- 1991b. "Morality, Identity, and Historical Explanation: Charles Taylor on the Sources of the Self," Sociological Theory 9 (2): 232-263.

- 1994a. Social Theory and the Politics of Identity. Cambridge, Mass. and Oxford UK: Black. well Publishers.

- 1994h. "Social Theory and the Politics of Identity." Pp. 9-36 in Social Theory and the Politics of Identity. Craig Calhoun, ed. Cambridge, Mass. and Oxford UK: Blackwell Publishers.

Dejean, Joan. 1997. Ancients Against Moderns: Culture Wars and the Making of a Fin de Siècle. Chicago: University of Chicago Press.

de Sousa, Ronald. 1987. The Rationality of Emotion. Cambridge: MIT Press.

Dunning, Eric. 1999. Sport Matters: Sociological Studies of Sport, Violence and Civilization. London \& New York: Routledge.

Dunning, Eric and Stephen Mennell. "Preface." Pp. vii-xvi in The Germans: Power Struggles and the Development of Habitus in the Nineteenth and Twentieth Centuries. By Norbert Elias. New York: Columbia University Press.

Durkheim, Emile. [1893] 1984. The Division of Labor in Society. Introduction by Louis Coser, translation by W. D. Halls. New York: Free Press.

Elias, Norbert. 1996. The Germans: Power Struggles and the Development of Habitus in the Nineteenth and Twentieth Centuries. Preface and translation by Eric Dunning and Stephen Mennell. New York: Columbia University Press.
- [1939] 2000. The Civilizing Process. Oxford. Blackwell Publishers.

Farberman, Harvey A. 1973. "Mannheim, Cooley, and Mead: Toward a Social Theory of Mentality." Pp. 261-272 in Toward the Sociology of Knowledge, Edited by G. W. Rem. mling. London: Routledge \& Kegan Paul.

Foucault, Michel. 1980. Power/Knowledge: Selected Interviews and Other Writings 1972-1977. New York: Pantheon.

- 1988. Technologies of the Self. Edited by L. H. Martin, H. Gutman, and P. H. Hutton. Amherst: University of Massachusetts Press.

Franks, David D. 1985. "Introduction: Special Issue on The Sociology of Emotions", Symbolic Interaction 8 (2): 161-170

Franks, David D. and E. Doyle McCarthy. 1989. The Sociology of Emotions: Original Essays and Research Papers. Greenwich, Connecticut: JAI Press.

Freud, Sigmund. [1923] 1960. The Ego and the Id. New York: W. W. Norton.

Gabler, Neal. 1998. Life the Movie: How Entertainment Conquered Reality. New York: Vintage/ Random House.

Gay, Peter. 1984. The Bourgeois Experience. Victoria to Freud. Vol. 1. Education of the Senses. New York: Oxford.

Gehlen Arnold. 1980. Man in the Age of Technology. New York: Columbia University Press. Gergen, Kenneth J. 1985. "The Social Constructionist Movement in Modern Psychology," The American Psychologist 40 (3): 266-75.

- 1991. The Saturated Self: Dilemmas of Identity in Contemporary Life. New York: Basic.

- 1999. An Invitation to Social Construction. London: Sage.

- 2001. "Psychological Science in a Postmodern Context," American Psychologist 56 (10): 803-813.

Gergen, Kenneth J. and K. Davis. 1985. The Social Construction of the Person. New York: Springer.

Giddens, Anthony. 1991. Modemity and Self-Identity. Stanford, California: Stanford University Press.

- 2000. The Runaway World: How Globalization Is Shaping Our Lives. New York: Routledge.

Goodwin, Jeff, James M. Jasper, and Francesca Polletta. 2001. Passionate Politics: Emotions and Social Movements. Chicago: University of Chicago Press.

Gordon, Steven L. 1981. "The Sociology of Sentiments and Emotions." Pp. 551-75 in Social Psychology: Sociological Perspectives, M. Rosenberg and R. Turner, eds. New York: Basic.

- 1989. "Institutional and Impulsive Orientations in the Selective Appropriation of Emotions to Self." Pp. 115-35 in The Sociology of Emotions, Franks, David D. and E. Doyle McCarthy, eds. Greenwich, CT: JAI Press.

Greenblatt, Stephen. 1980. Renaissance Self-Fashioning. Chicago, Illinois: University of Chicago Press.

Harré, Rom. 1986. The Social Construction of Emotions. London: Basil Blackwell

- 1991. Physical Being: A Theory for a Corporeal Psychology. Oxford: Basil Blackwell.

Hochschild, Arlie Russell. 1983. The Managed Heart: The Commercialization of Human Feeling. Berkeley, Ca.: University of California Press.

Illouz, Eva. 1997. Consuming the Romantic Utopia. Berkeley, CA: University of California Press.

Kane, Anne. 1997. "Theorizing Meaning Construction in Social Movements", Sociological Theory 15: 249-76. 
- 2001. "Finding Emotion in Social Movement Processes: Irish Land Movement Metaphor and Narratives." Pp. 251-266 in Passionate Politics: Emotions and Social Movements. Goodwin, Jeff, James M. Jasper, and Francesca Polletta, eds. Chicago: University of Chicago Press.

Katz, Jack. 1999. How Emotions Work. Chicago: University of Chicago Press.

Lash, Scott and Jonathan Friedman. 1992. Modemity and Identity. London: Blackwell.

Lewis, Jan and Peter N. Stearns. 1998. "Introduction." Pp. 1-14 in An Emotional History of the United States. Peter N. Stearns and Jan Lewis eds. New York: New York University Press.

Lévi-Strauss, Claude. [1962] 1969. Totemism. Translated by R. Needham. Introduction by R. C. Poole. New York: Penguin.

Lowney, Kathleen S. 1999. Baring Our Souls. Hawthorne, NY: Aldine de Gruyter.

Lupton, Deborah. 1998. The Emotional Self: A Sociocultural Exploration. London: Sage Publications.

Lutz, Catherine A. 1988. Unnatural Emotions. Chicago: University of Chicago Press.

- 1986. "The Domain of Emotion Worlds on Ifaluk." Pp. 267-88 in The Social Construction of Emotions. Edited by Rom Harré. Oxford: Blackwell.

Lynd, Helen Merrell. 1958. On Shame and the Search for Identity. New York: Harcourt Brace \& World.

McCarthy, E. Doyle. 1989a. "Emotions are Social Things." Pp. 51-72 in The Sociology of Emotions, edited by David D. Franks and E. Doyle McCarthy. Greenwich, CT: JAI Press.

- 1989b. "The Interactionist Theory of Mind: A Sociology of Social Objects," Studies in Symbolic Interaction. Norman K. Denzin ed., 10: 79-86.

- 1994. "The Social Construction of Emotions: Directions from Culture Theory," Social Perspectives on Emotion 2: 267-279.

- 1996. Knowledge As Culture: The New Sociology of Knowledge. New York and London: Routledge.

Parker, Andrew, Mary Russo, Doris Sommer, and Patricia Yeager. 1992. Nationalisms and Sexualities. New York and London: Routledge.

Percy, Walker. 1958. "Symbol, Consciousness and Intersubjectivity," Journal of Philosophy 55 631-641.

Reddy, William M. 1997. The Invisible Code: Honor and Sentiment in Postrevolutionary France, 1815-1848. Berkeley, CA: University of California Press.

- 2001. The Navigation of Feeling: A Framework for the History of Emotions. New York: Cambridge.

Rorty, Amelie O. 1980. Explaining Emotions. Berkeley: University of California Press.

Scheler, Max. 1954. The Nature of Sympathy. Translated by Peter Heath and Introduction by Werner Stark. New Haven: Yale University Press.

- 1961. Ressentiment. Translated by William W. Holdheim and Introduction by Lewis A. Coser. New York: Free Press.

Sennett, Richard. 1974. The Fall of Public Man: On the Social Psychology of Capitalism. New York: Random House.

Shweder, Richard A. and R. A. LeVine. 1984. Culture Theory: Essays on Mind, Self, and Emotions. New York: Cambridge.

Simmel, Georg. 1950. "The Secret and the Secret Society." Pp. 307-78 in The Sociology of Georg Simmel. Edited by Kurt Wolff, New York: Free Press.

Solomon, R. C. 1976. The Passions. Garden City, NY: Anchor Press/Doubleday.

- 1984. "Getting Angry: The Jamesian Theory of Emotion in Anthropology." Pp. 238-56 in Culture Theory. edited by R. A. Shweder and R. A. Levine. New York: Cambridge.
Stearns, Carol Zisowitz and Peter N. Stearns. 1986. Anger: The Struggle for Emotional Control in American History. Chicago: University of Chicago Press.

Stearns, Peter N. 1994. American Cool: Constructing A Twentieth Century Emotional Style. New York: New York University Press.

Stearns, Peter N. and Jan Lewis. 1998. An Emotional History of the United States. New York: New York University Press.

de Swaan, Abram. 1992. "Widening Circles of Identification: Emotional Concerns in Sociogenetic Perspective." Unpublished paper.

- 1990. The Management of Normality: Critical Essays in Health and Welfare. New York Routledge.

Swidler, Ann. 2001. Talk of Love. Chicago: University of Chicago Press.

Taylor, Charles. 1989. Sources of the Self: The Making of the Modern Identity. Cambridge, Mass.: Harvard University Press.

de Tocuueville, Alexis. [1840] 1990. Democracy in America. Vol. 2. New York: Vintage Books.

Turner, Ralph. 1976. "The Real Self from Institution to Impulse," American Joumal of Sociology 81 (5): 989-1016.

Williams, Raymond. 1973. The Country and the City. New York: Oxford.

- 1983. Keywords: A Vocabulary of Culture and Society. New York: Oxford.

Williams, Simon J. 2001. Emotion and Social Theory: Corporeal Reflections on the (Ir)Rational. London: Sage Publications.

Wouters, Cas. 1992. "On Status Competition and Emotion Management: The Study of Emotions as a New Field," Theory, Culture, and Society 9: 229-52.

- 1995. "Etiquette Books and Emotion Management in the 20th Century: Part One: The In tegration of Social Classes," Joumal of Social History 29 (1): 107-124.

- 1995. "Etiquette Books and Emotion Management in the 20th Century: Part Two: The Integration of the Sexes," Journal of Social History 29 (2): 325-339.

- 1998. "Changes in the 'lust balance' of sex and love since the sexual revolution: The example of the Netherlands." Chapter 13 in Emotions in Social Life: Critical Themes and Contemporary Issues. London and New York: Routledge.

- 1999. "Changing Patterns of Social Controls and Self-Controls," British Journal of Criminology 39 (3): 416-432. 